\title{
Antioxidant and cytoprotective activities of Piper betle, Areca catechu, Uncaria gambir and betel quid with and without calcium hydroxide
}

\author{
Nordin Nur Sazwi ${ }^{1+}$, Thurairajah Nalina ${ }^{2 \dagger}$ and Zubaidah Haji Abdul Rahim ${ }^{1^{* \dagger}}$
}

\begin{abstract}
Background: Betel quid chewing is a popular habit in Southeast Asia. It is believed that chewing betel quid could reduce stress, strengthen teeth and maintain oral hygiene. The aim of this study was to investigate the antioxidant and cytoprotective activities of each of the ingredients of betel quid and compared with betel quid itself (with and without calcium hydroxide). The correlation of their cytoprotective and antioxidant activities with phenolic content was also determined.
\end{abstract}

Methods: Five samples (betel leaf, areca nut, gambir, betel quid and betel quid containing calcium hydroxide) were extracted in deionized distilled water for 12 hours at $37^{\circ} \mathrm{C}$. Antioxidant activities were evaluated for radical scavenging activity using DPPH assay, ferric reducing activity using FRAP assay and lipid peroxidation inhibition activity using FTC assay. Total phenolic content (TPC) was determined using Folin-Ciocalteu procedure. Phenolic composition was analyzed using LC-MS/MS. Cytoprotective activity towards human gingival fibroblast cells was examined using MTT assay.

Results: Among the ingredients of betel quid, gambir demonstrated the highest antioxidant (DPPH $-\mathrm{IC}_{50}=6.4 \pm$ $0.8 \mu \mathrm{g} / \mathrm{mL}$, FRAP - $5717.8 \pm 537.6 \mu \mathrm{mol} \mathrm{Fe}(\mathrm{II}) / \mathrm{mg}$ ), total phenolic content (TPC - $1142.5 \pm 106.8 \mu \mathrm{g}$ TAE/mg) and cytoprotective $(100.1 \pm 4.6 \%)$ activities. Betel quid when compared with betel quid containing calcium hydroxide has higher antioxidant (DPPH $-I_{50}=59.4 \pm 4.4 \mu \mathrm{g} / \mathrm{mL}$, FRAP - 1022.2 $\pm 235.7 \mu \mathrm{mol} \mathrm{Fe}(\mathrm{II}) / \mathrm{mg}$ ), total phenolic content (TPC - 140.0 $\pm 22.3 \mu \mathrm{g} \mathrm{TAE} / \mathrm{mg}$ ), and cytoprotective (113.5 $\pm 15.9 \%)$ activities. However, all of the five samples showed good lipid peroxidation inhibition compared to vitamin E. LC-MS/MS analysis revealed the presence of quinic acid as the major compound of gambir and betel quid. A positive correlation was observed between TPC and radical scavenging $(r=0.972)$, reducing power $(r=0.981)$ and cytoprotective activity $(r=0.682)$.

Conclusions: The betel quid has higher TPC, and antioxidant and cytoprotective activities than betel quid with calcium hydroxide. The quinic acid in betel quid may play an important role in the oral health protection.

Keywords: Piper betle, Areca catechu, Uncaria gambir, Calcium hydroxide, Betel quid, Antioxidant, Cytoprotective, LC-MS/MS

\section{Background}

It has been reported that betel leaf, areca nut and gambir have a wide spectrum of therapeutic properties. The betel leaf has antiplaque [1], anti-diabetic and anti-inflammatory properties $[2,3]$ as well as anti-proliferative effect towards $\mathrm{KB}$ and HeLa cells [4]. Areca nut possesses significant

\footnotetext{
* Correspondence: zubaidar@um.edu.my

${ }^{\dagger}$ Equal contributors

'Department of Oral Biology, Faculty of Dentistry, University of Malaya, 50603 Kuala Lumpur, Malaysia

Full list of author information is available at the end of the article
}

analgesic and anti-inflammatory [5], wound healing [6] antidepressant [7] and anti-HIV activities [8]. The gambir has been used for the treatment of diarrhea, dysentery and as an astringent medicine in Asian countries [9]. Generally plants that have significant therapeutic properties were found to be rich in phenolics and have high antioxidant properties. This correlation has been confirmed with the antioxidant activity being detected in the extract of betel leaf [10] areca nut [11] and gambir [12].

\section{C) Biomed Central}

(c) 2013 Nur Sazwi et al.; licensee BioMed Central Ltd. This is an open access article distributed under the terms of the Creative Commons Attribution License (http://creativecommons.org/licenses/by/2.0), which permits unrestricted use, distribution, and reproduction in any medium, provided the original work is properly cited. 
The consumption of antioxidant-rich foods will help to neutralize the free radicals in the body, thus preventing or delaying the oxidative damage of lipids, proteins and nucleic acids [13]. It has been shown that the antioxidants could reduce mortality rate of cardiovascular disease [14,15], and protect against cancer and other chronic diseases [16]. In addition, many studies have reported that the antioxidant is highly associated with the cytoprotective activity of plant $[17,18]$. However, the plant antioxidant compounds that are responsible for reducing the risk of chronic disease have not been identified [19].

In Malaysia, the betel quid usually consists of dried areca nut, gambir and calcium hydroxide wrapped in betel leaf (personal communication with the local community in Gombak, Kuala Lumpur). The nut of Areca catechu is usually sun-dried and cut into pieces. Gambir is prepared by boiling the leaves and barks of Uncaria gambir of the family Rubiaceae in water. The liquid extracted from the plant are dried and molded into large size pellet. Calcium hydroxide (also known as slaked lime) is usually made from burnt and crushed seashell.

It has been claimed that chewing betel quid could strengthen teeth and gums and maintain oral hygiene [20]. Betel quid chewing has been practiced for centuries and it is the fourth typical habit in the world after nicotine, alcohol and caffeine consumption [21] with an estimate of 600 million betel quid chewers worldwide [22]. This habit is popular among the elderly and lower income population in rural areas, primarily in Southeast Asia and has become part of their social and cultural practices [23]. Betel quid is chewed to reduce stress, increase alertness and produce feelings of psychological well-being $[24,25]$. It gives a warm and bitter taste with aroma, and produces red juice, which would stain teeth red.

At present, there are limited researches on antioxidant and cytoprotective activities of betel quid. Hence in this study, the antioxidant and cytoprotective activities of betel quid (with and without calcium hydroxide) were evaluated and compared with those of its respective ingredients. The correlation of the antioxidant and cytoprotective activities with phenolic content was also determined.

\section{Methods}

\section{Chemicals and reagents}

Folin-Ciocalteu's phenol reagent and ferric chloride tetrahydride were purchased from MERCK (Germany). Ethanol and ascorbic acid were purchased from Fisher Scientific (USA). Hydrochloric acid, monosodium phosphate and disodium phosphate were purchased from $\mathrm{R}$ \& M Chemicals (UK). Alpha-tocopherol, linoleic acid, DPPH (1,1- diphenyl-2-picrylhydrazyl) and TPTZ (2,4,6tripyridy-s-triazine) were purchased from Sigma-Aldrich Inc. (USA). Tannic acid was purchased from Bendosen
(UK). Dulbecco's modified eagle medium (DMEM) (11960-044) and fetal bovine serum (10270-098) were purchased from Gibco BRL (USA). Ammonium thiocyanate, phosphate buffer saline, gelatine (from bovine skin), dimethyl sulfoxide (DMSO), 3-(4,5-dimethylthiazole-2-yl)2,5-diphenyl-tetrazoliumbromide (MTT) were purchased from Sigma-Aldrich Inc. (USA). Penicillin/streptomycin (100×), fungizone (Amphotericin B, $250 \mu \mathrm{g} / \mathrm{mL}$ ), acutase cell detachment solution were purchased from PAA (UK).

\section{Sample collection}

Fresh betel leaves (Piper betle) were purchased fresh from one source in Keramat, Kuala Lumpur. The herbarium voucher specimen was authenticated and identified by the morphology and fragrance of the leaves by Mr Kamarudin Saleh from the Herbarium Unit of the Forest Research Institute Malaysia (FRIM, Kepong, Selangor, Malaysia). The betel leaves were prepared and deposited according to the regulation specified by the FRIM Herbarium. The voucher number for Piper betle leaves is PID 411113-20.

The processed form of gambir and the dried form of areca nut and calcium hydroxide were purchased from a shop at the Chow Kit market in Kuala Lumpur, Malaysia and all were purchased at three different times (in order to prepare three sets of extractions) started from June to December 2010.

\section{Preparation of the aqueous extract of betel quid (with and without calcium hydroxide) gambir, areca nut and betel leaf}

A $10 \%$ aqueous sample extract was prepared according to the following procedure. A known weight of betel leaf was homogenized in deionized distilled water that was placed in an incubator shaker at $37^{\circ} \mathrm{C}$ for 12 hours. This was followed by filtration using No.1 filter paper (Whatman, USA) before concentrating using a rotary evaporator. The concentrated extract was then freeze-dried and stored at $-20^{\circ} \mathrm{C}$ until further use. The procedure was repeated with areca nut, gambir, betel quid and betel quid containing calcium hydroxide. The betel quid was prepared using betel leaves, areca nut and gambir in the proportion of 46:3:1. The betel quid with calcium hydroxide was prepared using the proportion 43:3:1:3 for betel leaves: areca nut: gambir: calcium hydroxide respectively. This is the proportion that is popularly consumed by the locals in Malaysia (personal communication). For each of the samples, three different extract preparations were carried out. $\mathrm{pH}$ of the respective extracts were measured and recorded prior use.

\section{DPPH radical scavenging activity}

The radical-scavenging activity of the extracts against 1,1-diphenyl-2-picrylhydrazyl (DPPH) was assessed using the method described by Manigauha and Maheshwari 
[26]. Ascorbic acid was used as a positive control while the DPPH-ethanol mixture without the extract was used as the blank control. The percentage inhibition of DPPH radical was calculated using the following formula:

$$
\begin{array}{r}
\text { Inhibition Percentage }=\left(A_{\text {blank control }}-A_{\text {sample }}\right) \\
/ A_{\text {blank control }} \times 100
\end{array}
$$

where A sample is the absorbance of extracts/ascorbic acid and $\mathrm{A}$ blank control is the absorbance of the blank control. The antioxidant activity was expressed as $\mathrm{IC}_{50}$ value, which is defined as the amount of antioxidant that is required to decrease the initial $\mathrm{DPPH}$ concentration by $50 \%$.

\section{Ferric reducing activity}

The ferric reducing activity of the extracts was determined using the ferric reducing antioxidant power (FRAP) assay developed by Benzie and Strain [27]. The FRAP reagent was freshly prepared by mixing $10 \mathrm{mM}$ TPTZ solution in $40 \mathrm{mM} \mathrm{HCl}, 20 \mathrm{mM} \mathrm{FeCl3}, 300 \mathrm{mM}$ acetate buffer ( $\mathrm{pH}$ 3.6) in proportions of 1:1:10 (v/v/v). Ten $\mu \mathrm{L}$ of extract (1 mg dissolved in $1 \mathrm{~mL}$ deionised distilled water) was dispensed into a 96- well microplate. Subsequently $200 \mu \mathrm{L}$ of freshly prepared FRAP reagent that has been warmed at $37^{\circ} \mathrm{C}$ was dispensed into the same well of 96-well microplate containing the extract. The mixture was then mixed and the absorbance was measured after $4 \mathrm{~min}$ at $593 \mathrm{~nm}$ using a microplate reader (Power Wave-X340 Bio-tek instruments Inc.). Ferrous sulphate (concentrations ranging from 200 to $1000 \mu \mathrm{M}, \mathrm{R}^{2}=0.9940$ ) was used to plot the standard curve. Ascorbic acid was used as the reference. The FRAP was expressed as micromoles of ferrous equivalents, Fe(II) per mg of extract.

\section{Inhibition of lipid peroxidation activity}

The inhibition of lipid peroxidation activity of the extracts was carried out using ferric thiocyanate (FTC) assay described by Osawa and Namiki [28]. To prepare a stock mixture of the extract, $4 \mathrm{~mL}$ of extract $(50 \mu \mathrm{g} / \mathrm{mL})$ in $95 \%(\mathrm{w} / \mathrm{v})$ ethanol was added to $4.1 \mathrm{~mL}$ of linoleic acid $(2.5 \%, \mathrm{v} / \mathrm{v})$ in $99.5 \%$ ethanol, followed by $8 \mathrm{~mL}$ of $0.05 \mathrm{M}$ phosphate buffer $\mathrm{pH} 7.0$ and $3.9 \mathrm{~mL}$ of distilled water. The stock mixture was then kept in an incubator at $40^{\circ} \mathrm{C}$ in a dark bottle loosely capped until further use. For measurement of the antioxidant property of the extract, $0.1 \mathrm{~mL}$ of the stock mixture was added to a mixture containing $9.7 \mathrm{~mL}$ of $75 \%$ ethanol $(\mathrm{w} / \mathrm{v}), 0.1 \mathrm{~mL}$ of $30 \%$ ammonium thiocyanate $(\mathrm{w} / \mathrm{v})$ and $0.1 \mathrm{~mL}$ of $20 \mathrm{mM}$ ferrous chloride in $3.5 \%(\mathrm{v} / \mathrm{v})$ hydrochloric acid. After exactly $3 \mathrm{~min}$, the absorbance reading of the complex formed was measured at $500 \mathrm{~nm}$ and the reading was repeated at every 24 hours for eight days. For blank control, $4 \mathrm{~mL}$ of ethanol $(95 \% \mathrm{w} / \mathrm{v})$ and for positive control $4 \mathrm{~mL}$ of $\alpha$-tocopherol $(50 \mu \mathrm{g} / \mathrm{mL})$ was added instead of the extract. The antioxidant activity was determined by calculating the percentage of lipid peroxidation inhibition using the formula:

$$
\text { Inhibition Percentage }=\left(\mathrm{A}_{\text {control }}-\mathrm{A}_{\text {sample }}\right) / \mathrm{A}_{\text {control }} \times 100
$$

\section{Determination of total phenolic content}

Total phenolic content of the extracts was determined using modified version of Folin-Ciocalteu method described by Chandler and Dodds [29] and Shetty et al. [30]. One mg of each extract was respectively dissolved in $1 \mathrm{~mL}$ deionised distilled water and this was subsequently diluted with the addition of another $4 \mathrm{~mL}$ of the distilled water. This was followed by the addition of $0.5 \mathrm{~mL}$ of $50 \%$ FolinCiocalteu reagent. The mixture was then vortexed and left for 5 mins at room temperature. One $\mathrm{mL}$ of sodium carbonate $(5 \% \mathrm{w} / \mathrm{v})$ was then added and after mixing thoroughly, the mixture was incubated in the dark for 1 hour at room temperature, after which its absorbance was measured at $725 \mathrm{~nm}$ using UV/Vis spectrophotometer (Shimadzu UV-1800, Japan). Tannic acid (concentration ranging from 5 to $80 \mu \mathrm{g} / \mathrm{mL}, \mathrm{R}^{2}=0.9993$ ) was used to plot the standard curve. The TPC was expressed as $\mu \mathrm{g}$ of tannic acid equivalents (TAE) per mg dried extract.

\section{Analysis of phenolic composition}

The extracts $(0.002 \mathrm{~g} / \mathrm{mL})$ were filtered using $0.2 \mathrm{~mm}$ nylon membrane filters prior to injection into the HPLC. The chromatographic system was consisting of a binary pump 200 series HPLC apparatus (Agilent Technologies, USA), coupled with an AB Sciex hybrid triple quadrupole mass spectrometer (AB Sciex, Canada) with a vacuum degasser, binary gradient pump and auto sampler. A Phenomenex Aqua-C18 column $(2.0 \mathrm{~mm} \times 50 \mathrm{~mm}$, I.D. $5 \mathrm{~mm}$ ) was used for the separation at a flow rate between 0.25 and $0.4 \mathrm{~mL} / \mathrm{min}$. The mobile phase was a gradient of $0.1 \%$ formic acid in water and $5 \mathrm{mM}$ ammonium formate (solvent A) and $0.1 \%$ formic acid in acetonitrile and $5 \mathrm{mM}$ ammonium formate (solvent B) with the following gradient programme: $0.01-8 \mathrm{~min}, 10 \% \mathrm{~A}$ to $90 \% \mathrm{~B}$ and hold for $2 \mathrm{~min}$ and back to $10 \% \mathrm{~A}$ in $0.1 \mathrm{~min}$ and re-equilibrated for $5 \mathrm{~min}$. Total run time is $15 \mathrm{~min}$.

The ESI-MS conditions were as follows: negative-ion mode; ionization voltage, $-4.5 \mathrm{kV}$; drying and nebulizer gas is purified $\mathrm{N}_{2}$, total flow rate $34 \mathrm{~L} \cdot \mathrm{min}-1$; temperature, $500^{\circ} \mathrm{C}$ and pressure of nebulizer gas, 110 psi. Mass detection was performed in full scan mode in the range 100$1200 \mathrm{~m} / \mathrm{z}$.

The ESI-MS/MS conditions: collision gas is purified nitrogen gas. The collision energy is an average collision energy spread between $20 \mathrm{eV}, 35 \mathrm{eV}$ and $50 \mathrm{eV}$. Data analysis was acquired by $\mathrm{AB}$ Sciex Analyst 1.5 workstation 
and based on spectral MS/MS library match, with additional information from reference journal, and utilizing advanced chemometrics software data processing and interpretation with fragmentation prediction (ACD/Labs MS Fragmenter).

\section{Primary culture of human gingival fibroblast cells}

The primary explant technique is a modified version described by Freshney [31]. Freshly extracted teeth with gingival tissues were collected from the Oral Surgery Department, Faculty of Dentistry, University of Malaya, Kuala Lumpur, Malaysia. The teeth were then placed in basic media of DMEM. Only tooth that was sound or healthy was selected for this procedure. The selected tooth was then washed with phosphate buffered saline and disinfected using penicillin/streptomycin solution for 2-3 min to kill any bacteria, and then rinsed with DMEM. The gingival tissue specimens were sliced into pieces, approximately $1 \times 1 \mathrm{~mm}$ in size by using sterilized sharp scalpels. The tissues were then transferred into a $1.5 \mathrm{~mL}$ sterile centrifuge tube containing $1 \mathrm{~mL}$ of DMEM and penicillin/streptomycin solution (1:1 v/v) and gently resuspending them by pipetting up and down for a few seconds. The media were discarded, rinsed twice with DMEM and replaced with $1 \mathrm{~mL}$ of DMEM supplemented with $10 \%(\mathrm{v} / \mathrm{v})$ fetal bovine serum (FBS).
The tissues were then transferred and carefully spread into the T25 flask coated with $0.1 \%$ gelatin. The tissues were incubated in a humid $5 \% \mathrm{CO}_{2}$ incubator at $37^{\circ} \mathrm{C}$ to allow the attachment of the tissue to the surface of the flask. After one hour, an additional $500 \mu \mathrm{L}$ of DMEM supplemented with $10 \%$ FBS was added into the flask, just enough to moisten the tissue. After 24 hours incubation, the medium was removed and gently replaced with $2 \mathrm{~mL}$ of DMEM supplemented with 10\% FBS. The medium was replaced with a fresh medium every 3 days until the cells reached $70-80 \%$ confluence.

\section{Cytoprotective activity}

$100 \mu \mathrm{L}$ of media (DMEM supplemented with $10 \%$ FBS) containing HGF cells at a density of $6 \times 10^{3}$ cells/well were seeded in 96-well plates and incubated in a humid $5 \% \mathrm{CO}_{2}$ incubator at $37^{\circ} \mathrm{C}$ for 8 hours (Figure 1). The media were then aspirated and replaced with fresh media containing extracts at different concentrations $(12.5,25$, 50 and $100 \mu \mathrm{g} / \mathrm{mL}$ ) and allowed to incubate for 16 hours. The media were discarded and rinsed with PBS. A media containing $0.7 \mathrm{mM}$ of hydrogen peroxide was then added and incubated for 6 hours. The media were then discarded and $25 \mu \mathrm{L}$ of freshly prepared MTT solution $(5 \mathrm{mg} / \mathrm{mL}$ of PBS) was added and allowed to incubate for 4 hours. The supernatant was removed and the formazan blue crystals formed were dissolved in $150 \mu \mathrm{L}$ of DMSO. The

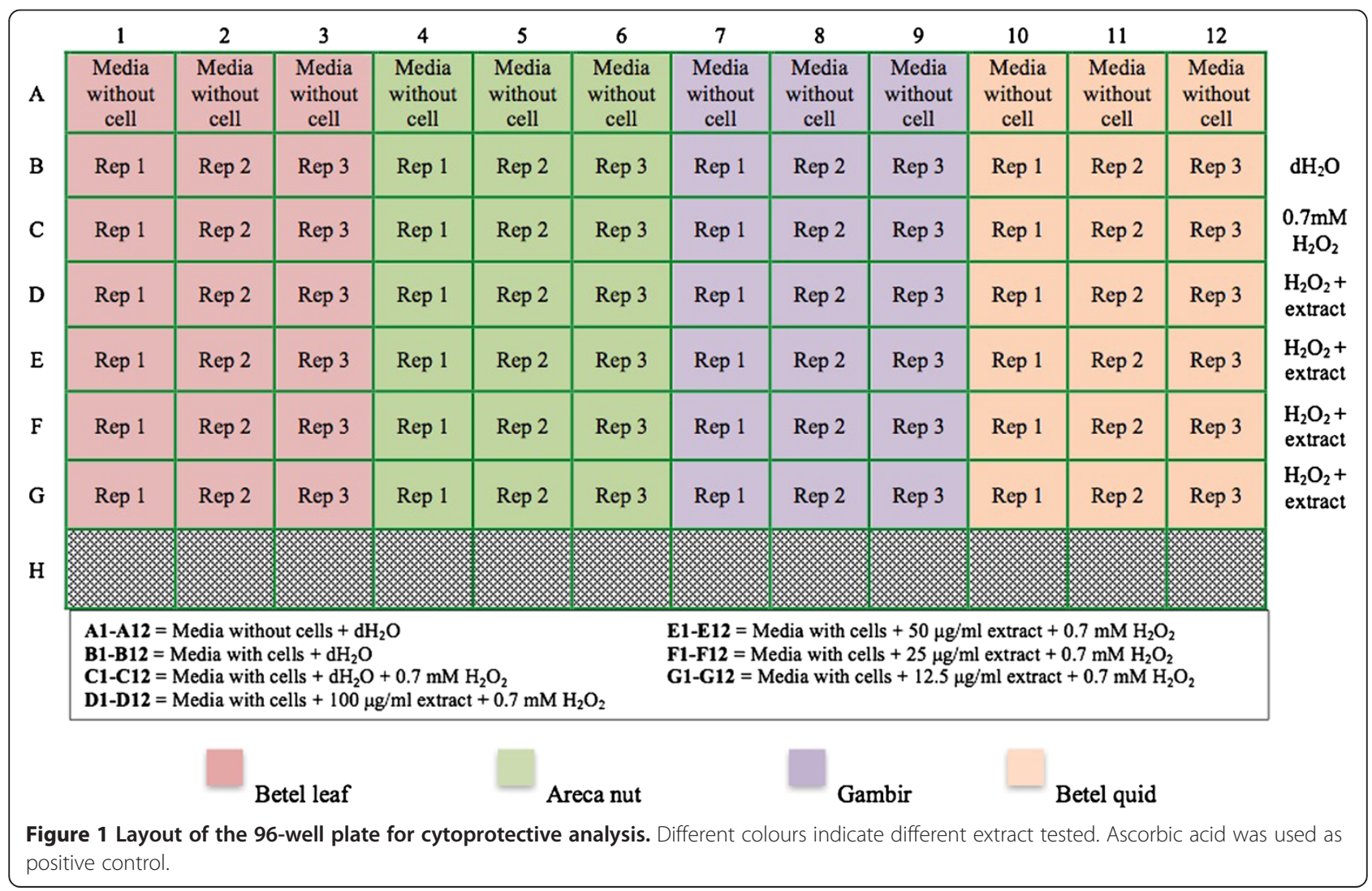


absorbance of the dissolved formazan blue cyrstal was measured at $570 \mathrm{~nm}$ using a microplate ELISA reader (Biotek U-quant, USA). The blank control referred as wells containing cells without the treatment of sample extract and hydrogen peroxide (deionized distilled water was used instead of the sample extract and hydrogen peroxide). For positive control, ascorbic acid was used. The percentage of cell viability was calculated with the following equation:

$$
\text { Cell viability }(\%)=\left(\mathrm{A}_{0}-\mathrm{A} / \mathrm{A}_{1}\right) \times 100 \%
$$

Where A was the absorbance of sample blank, $A_{1}$ was the absorbance of the cells in the blank control and $\mathrm{A}_{0}$ was the absorbance of the cells (1) in the presence of the extract/ascorbic acid and (2) in the absence of extract after exposure with hydrogen peroxide. In the experiment, HGF used was from the fifth passage through eight passages.

\section{Statistical analysis}

The experiments were repeated using three different sets of freshly prepared extracts and each of which was analyzed in triplicate and the result expressed as mean \pm standard deviation (SD). For cytoprotective activity, the experiment was also analyzed in triplicate and expressed as mean \pm standard deviation. Data were analyzed using SPSS statistical software, version 19.0 (SPSS Inc, Chicago, IL, U.S.A.). The tests were divided into two statistical tests, parametric and non-parametric tests. The parametric test includes one-way ANOVA and t-test, and the non-parametric test includes Kuskal Wallis test and Mann Whitney test. The $p<0.05$ was considered significant whereas $p<0.01$, highly significant. For correlation studies, Pearson's correlation coefficient ( $r$ ) was performed.

\section{Results}

Radical scavenging activity

Gambir exhibited the highest antioxidant activity by strongly inhibiting $50 \%$ of DPPH radicals at a lower concentration and was as potent as ascorbic acid (Table 1).
However, betel quid with calcium hydroxide was unable to scavenge $50 \%$ of $\mathrm{DPPH}$ radicals even at the highest concentration tested $(1 \mathrm{mg} / \mathrm{mL})$. The $\mathrm{IC}_{50}$ of the extracts can be described in the following order: gambir $>$ areca nut $>$ betel quid $>$ betel leaf $>$ betel quid with calcium hydroxide.

\section{Ferric reducing activity}

Similar pattern was observed with radical scavenging activity, ferric reducing activity was highest for the gambir extract and this was followed in descending order by the areca nut, betel quid, betel leaf and betel quid with calcium hydroxide (Table 1). In comparison with ascorbic acid, gambir is 3-folds lower in its ability to reduce the ferric ion.

\section{Inhibition on lipid peroxidation}

All of the extracts demonstrated higher inhibition of lipid peroxidation compared to $\alpha$-tocopherol at a concentration of $50 \mu \mathrm{g} / \mathrm{mL}$ after seven days of incubation (Table 1). The percentage of lipid peroxidation inhibition can be described in the following order: betel leaf $>$ betel quid $>$ betel quid with calcium hydroxide $>$ areca nut $>$ gambir. However, there was no significant difference in the inhibition activity among the extracts $(p>0.05)$.

\section{Total phenolic contents}

It was found that the gambir extract has the highest TPC followed by areca nut (Table 1). The TPC of betel quid was 3-folds higher than the TPC of betel quid with calcium hydroxide. The TPC of betel quid with calcium hydroxide was the lowest. The TPC of the betel leaf was 1.8-folds lower than the TPC of betel quid but 1.7-folds higher than the TPC of betel quid with calcium hydroxide.

\section{Analysis of phenolic compounds using LC-MS/MS}

Table 2 shows the LC-MS/MS analysis showing the presence of eugenol in all of the betel leaf-based samples, which was highest in the betel leaf itself, followed by the betel quid and subsequently, the betel quid with calcium hydroxide. The major compound in betel leaf was $p$ -

Table 1 Total phenolic and antioxidant activities of aqueous extract of plant materials

\begin{tabular}{|c|c|c|c|c|}
\hline Sample & TPC ( $\mu \mathrm{g}$ TAE/mg) & $\mathrm{DPPH}\left(I C_{50}\right) \mu \mathrm{g} / \mathrm{mL}$ & FRAP $(\mu \mathrm{mol} \mathrm{Fe}(\mathrm{II}) / \mathrm{mg})$ & $\begin{array}{l}\text { *Lipid peroxidation } \\
\text { inhibition (\%) }\end{array}$ \\
\hline Betel leaf & $77.2 \pm 12.6$ & $179.5 \pm 93.1$ & $357.3 \pm 129.5$ & $83.0 \pm 0.2$ \\
\hline Areca nut & $858.8 \pm 53.9$ & $7.5 \pm 0.5$ & $4127.8 \pm 192.8$ & $78.8 \pm 1.0$ \\
\hline Gambir & $1142.5 \pm 106.8$ & $6.4 \pm 0.8$ & $5717.8 \pm 537.6$ & $75.2 \pm 1.2$ \\
\hline Betel quid & $140.0 \pm 22.3$ & $59.4 \pm 4.4$ & $1022.2 \pm 235.7$ & $82.7 \pm 0.9$ \\
\hline Betel quid $+\mathrm{CaOH}_{2}$ & $45.4 \pm 3.7$ & Not detected & $71.8 \pm 29.8$ & $82.2 \pm 0.5$ \\
\hline Positive control & - & $4.8 \pm 0.5^{\mathrm{a}}$ & $16813.3 \pm 131.1^{\mathrm{a}}$ & $18.1 \pm 2.8^{b}$ \\
\hline
\end{tabular}

Values are expressed as means \pm SD $(n=9)$. Values within each column were significantly difference at $p<0.05$ (Kruskall Wallis test). Positive control: ${ }^{a}$ Ascorbic acid and ${ }^{\mathrm{b}} \mathrm{a}$-tocopherol. *Sample tested at concentration $50 \mu \mathrm{g} / \mathrm{mL}$ after seven days of incubation. 
Table 2 The composition of phenolic compounds in betel quid (with and without calcium hydroxide) and that of its ingredients

\begin{tabular}{|c|c|c|c|c|}
\hline$t_{\mathrm{R}}(\min )$ & MW (calculated mass) & $\mathrm{M}-\mathrm{H}$ (observed mass) & Proposed compound & Area (\%) \\
\hline \multicolumn{5}{|c|}{ Betel leaf } \\
\hline 1.454 & 138.03 & 137.07 & p-hydroxybenzoic acid* & 44.9 \\
\hline 2.102 & 164.16 & 163.09 & Eugenol & 2.95 \\
\hline 2.427 & 338.19 & 337.19 & 4-p-coumaroylquinic acid & 1.6 \\
\hline \multicolumn{5}{|c|}{ Areca nut } \\
\hline 1.128 & 866 & 865.20 & Procyanidin trimer & 1.56 \\
\hline 1.290 & 578 & 577.12 & Procyanidin dimers (B1) & 25.34 \\
\hline 1.614 & 290.26 & 289.19 & Catechin* & 41.44 \\
\hline 2.585 & 866 & 865.37 & Procyanidin trimers & 2.93 \\
\hline 2.909 & 578 & 577.24 & Procyanidin dimers (B2) & 0.6 \\
\hline 3.718 & 624 & 623.16 & isorhamnetin 3-O-rutinoside & 3.53 \\
\hline \multicolumn{5}{|l|}{ Gambir } \\
\hline 0.805 & 192.17 & 191.05 & Quinic acid* & 21.77 \\
\hline 1.293 & 290.26 & 289.17 & $(+)$-catechin & 6.02 \\
\hline 1.619 & 578.52 & 577.19 & Procyanidin dimer (B1) & 17.96 \\
\hline 2.268 & 562 & 561.12 & (epi)afzelechin-(epi)catechin & 7.06 \\
\hline 2.431 & 580.1 & 579.10 & Proanythocyanidin dimer & 12.16 \\
\hline 2.593 & 578.52 & 577.15 & Proanthocyanidin dimer & 0.8 \\
\hline 2.917 & 290.26 & 289.12 & (-)-epicatechin & 1.61 \\
\hline 3.726 & 290.26 & 289.12 & Catechin Isomer & 5.34 \\
\hline 5.505 & 578.52 & 577.11 & Proanthocyanidin dimer & 3.05 \\
\hline 5.342 & 580.1 & 579.10 & Proanthocyanidin dimer & 3.07 \\
\hline 6.28 & 610 & 609.19 & Quercetine diglycoside & 14.79 \\
\hline 6.649 & 450.39 & 451.22 & Cyanidin-3-O-glucoside & 4.3 \\
\hline 7.631 & 302.24 & 301.11 & Quercetin & 2.02 \\
\hline 8.116 & 286.06 & 285.08 & Kaempferol & 0.05 \\
\hline \multicolumn{5}{|c|}{ Betel quid } \\
\hline 0.969 & 192.17 & 191.07 & Quinic acid* & 10.76 \\
\hline 1.295 & 164 & 163.08 & p-coumaric acid & 4.55 \\
\hline 2.426 & 164 & 163.05 & Eugenol & 3.89 \\
\hline 2.587 & 134.18 & 133.02 & Chavicol & 1.26 \\
\hline 3.071 & 138.03 & 137.03 & p-hydroxybenzoic acid & 1.52 \\
\hline 6.460 & 150.174 & 149.08 & hydroxychavicol & 0.62 \\
\hline 8.078 & 330 & 329.24 & 3,30-di-O-methyl ellagic acid & 0.16 \\
\hline \multicolumn{5}{|c|}{ Betel quid with calcium hydroxide } \\
\hline 1.453 & 164.2 & 163.05 & Eugenol & 1.37 \\
\hline 2.425 & 164.2 & 163.04 & p-coumaric acid & 1.61 \\
\hline 7.098 & 150.174 & 149.07 & Hydroxychavicol* & 2.1 \\
\hline
\end{tabular}

*Major compound in the aqueous extracts.

hydroxybenzoic acid and in gambir was quinic acid. It was shown that betel quid has both $p$-hydroxybenzoic acid and quinic acid but in smaller amount. For the areca nut, the major compound was found to be catechin. Both $p$ - coumaric acid and hydroxychavicol were present in the betel quid and betel quid with calcium hydroxide. The betel quid contained lower hydroxychavicol and higher $p$ coumaric acid than betel quid with calcium hydroxide. 


\section{Cytoprotective effects of the extracts on HGF cells exposed to hydrogen peroxide}

Preliminary study by MTT assay showed that all of the extracts were not toxic up to a concentration of $500 \mu \mathrm{g} / \mathrm{mL}$. Ascorbic acid was observed to be toxic at $500 \mu \mathrm{g} / \mathrm{mL}$ (Figure 2). Subsequent studies for cytoprotective effect used the extracts with concentration below $100 \mu \mathrm{g} / \mathrm{mL}$.

Figure 3 shows that the exposure of the cells to $0.5 \mathrm{mM}$ hydrogen peroxide resulted in $53.1 \pm 7.0 \%$ cell survival while the exposure with $1 \mathrm{mM}$ hydrogen peroxide resulted in significant cell death with $9.2 \pm 2.2 \%$ cell survival. Using this as a reference, the concentration of hydrogen peroxide that will be used to induce stress to the cells before treatment with the extract was $0.7 \mathrm{mM}$.

\section{Cytoprotective activity}

At $0.7 \mathrm{mM}$, hydrogen peroxide decreased cell viability to $34.9 \pm 6.0 \%$ of that of the control (Figure 4). Areca nut, gambir and betel quid extracts exhibited strong cytoprotective effect at a concentration of $50 \mu \mathrm{g} / \mathrm{mL}$ with cell viability of $89.3 \pm 9.4 \%, 100.1 \pm 4.6 \%$ and $113.5 \pm 15.9 \%$ respectively. This effect was comparable to that of ascorbic acid at a concentration of $50 \mu \mathrm{g} / \mathrm{mL}$ with cell viability of $82.4 \pm 2.1 \%$. The extracts of betel leaf and betel quid with calcium hydroxide at concentration $50 \mu \mathrm{g} / \mathrm{mL}$; however, demonstrated slight cytoprotective effect against hydrogen peroxide-induced oxidative stress with $52.1 \pm$ $11.7 \%$ and $41.5 \pm 0.5 \%$ of cell viability respectively. The betel quid extract was also cytoprotective at a lower concentration of $(12.5 \mu \mathrm{g} / \mathrm{mL})$ with cell viability of $72.4 \pm 5.9 \%$ while other extracts gave negligible cytoprotective effects (cells viability of $42.7 \pm 3.4 \%$ for the betel leaf and $45.5 \pm$
$5.9 \%$ for the gambir). Both the areca nut and betel quid with calcium hydroxide failed to protect the cells from hydrogen peroxide-induced stress at concentration of $12.5 \mu \mathrm{g} / \mathrm{mL}$ with cells viability of $28.5 \pm 1.1 \%$ for the areca nut and $35.2 \pm 1.3 \%$ for the betel quid with calcium hydroxide.

\section{Correlation of total phenolic content with antioxidant and cytoprotective activities}

A positive and strong correlation ( $r$ ) exists between TPC and DPPH radical scavenging and ferric reducing activity (Table 3). However a negative and strong correlation was observed between TPC and inhibition of lipid peroxidation activity $(p<0.01)$. The correlation between the TPC and cytoprotective activity was positive but less strong.

\section{Discussion}

Betel quid is chewed in the oral cavity where it remains for some time, releasing its water-soluble components into the oral environment. Thus, a temperature of $37^{\circ} \mathrm{C}$ was set for the extraction using aqueous medium to emulate the condition in the oral cavity. In the DPPH and FRAP assays, it was shown that the gambir, one of the ingredients of betel quid exhibited a marginally better antioxidant activity than the areca nut. In addition, the DPPH scavenging activity of gambir is almost similar with ascorbic acid, indicating its powerful free radical scavenger. DPPH assay measures the ability of the extract to donate hydrogen to the DPPH radical resulting in bleaching of the DPPH solution. The greater the bleaching action, the higher is the antioxidant activity. The DPPH

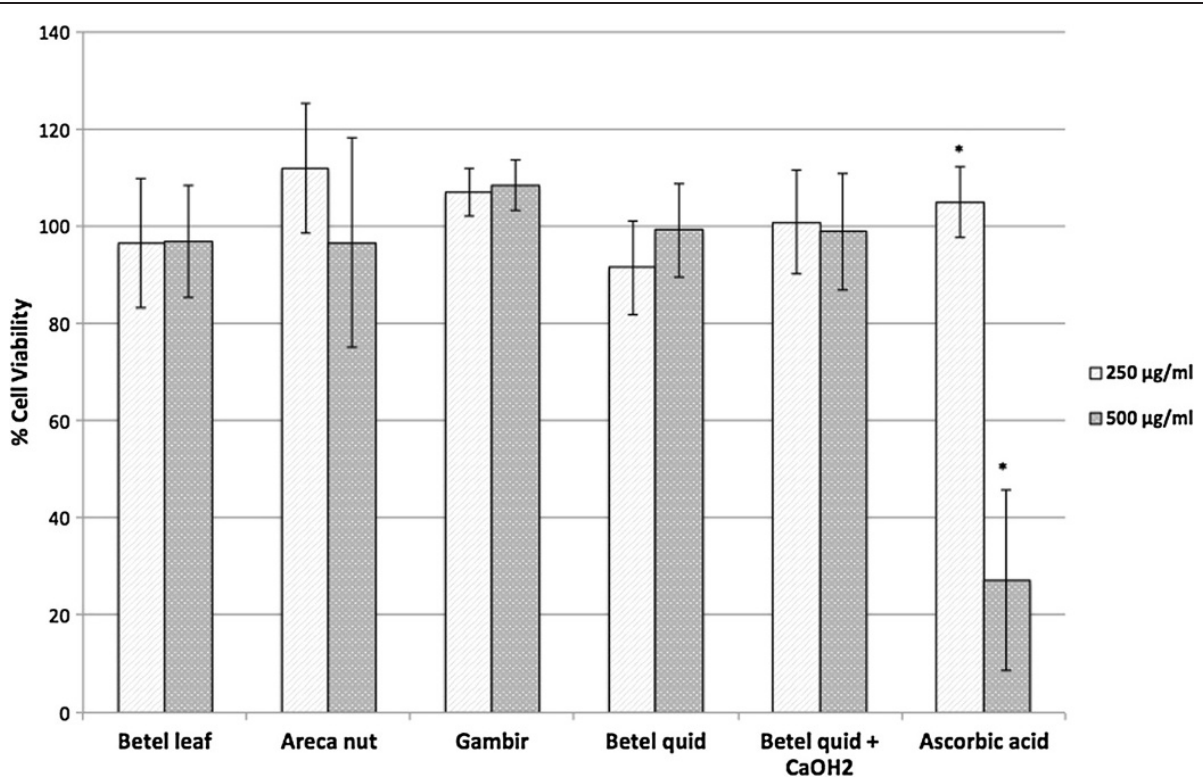

Figure 2 Effects of extracts on human gingival fibroblast cells. Cell viability was determined by MTT assay. Values are expressed as means \pm $\mathrm{SD}(\mathrm{n}=3)$. *Significant difference at $p<0.05$ (t-test). 


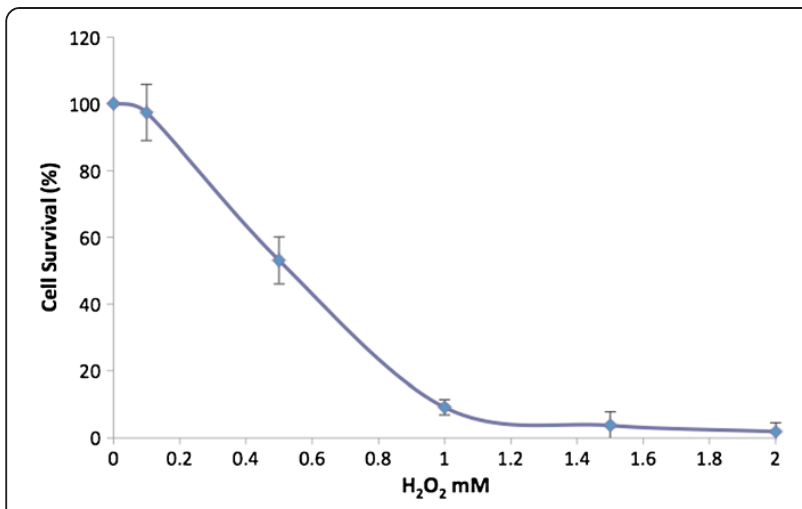

Figure 3 Effects of hydrogen peroxide on human gingival fibroblast cells. Cell viability was determined by MTT assay. Values are expressed as means \pm SD $(n=9)$.

radical scavenging activity of the areca nut was comparable with what has been reported by Khan et al. [32].

The gambir extract also exhibited a strong antioxidant activity by reducing ferric ion $\left(\mathrm{Fe}^{3+}\right)$ to ferrous $\left(\mathrm{Fe}^{2+}\right)$ in FRAP assay. According to Alothman et al. [33], DPPH and FRAP assays share similar mechanism of reaction, that is to reduce certain radicals (e.g. ferric ion and DPPH radical). Thus the higher the scavenging DPPH-radical activity, the higher is the ferric reducing ability.

The DPPH radical scavenging and ferric reducing activities of betel quid containing calcium hydroxide were observed to be the lowest. This may be due to the alkalinity of the calcium hydroxide (the $\mathrm{pH}$ of betel quid with calcium hydroxide in aqueous solution was 7.69). Settharaksa et al. [34] have reported that an alkaline $\mathrm{pH}$ reduced total phenolic content and DPPH radical scavenging activity.

However, the extract of betel quid containing calcium hydroxide exhibited similar antioxidant activity with the other extracts in inhibiting the lipid peroxidation as measured in FTC assay. Moreover, all of the extracts demonstrated higher inhibitory effect towards the lipid peroxidation compared to $\alpha$-tocopherol, indicating that the extracts are stronger lipid peroxidation inhibitor than the $\alpha$-tocopherol. Previous study done by Maznah et al. [35] have reported that their extracts had the highest antioxidant activity compared with $\alpha$-tocopherol, and the same finding was also reported by Huda-Faujan et al. [36], Hu et al. [37] and Aqil et al. [38].

The total phenolic content (TPC) in gambir was found to be the highest compared with the other extracts. This may be due to its high content of phenolic compounds as determined by the LC-MS/MS (Table 2). Other studies have reported that the gambir contains quinic acid [39], catechin [12,40], epicatechin [41], and procyanidin dimers B-1 [42]. The betel quid containing calcium hydroxide has low content of phenolics which corresponds to its low TPC. The free radical scavenging and ferric reducing activities of the extracts were strongly and positively correlated with its total phenolic content due to similar mechanisms involved in the assays. Folin-Ciocalteu method in TPC assay is based on the mechanism of oxidation and reduction $[43,44]$, which is the same with the mechanism exhibited by free radical scavenging and ferric reducing activities. Thus, the higher the TPC, the stronger is the DPPH radical scavenging and ferric reducing

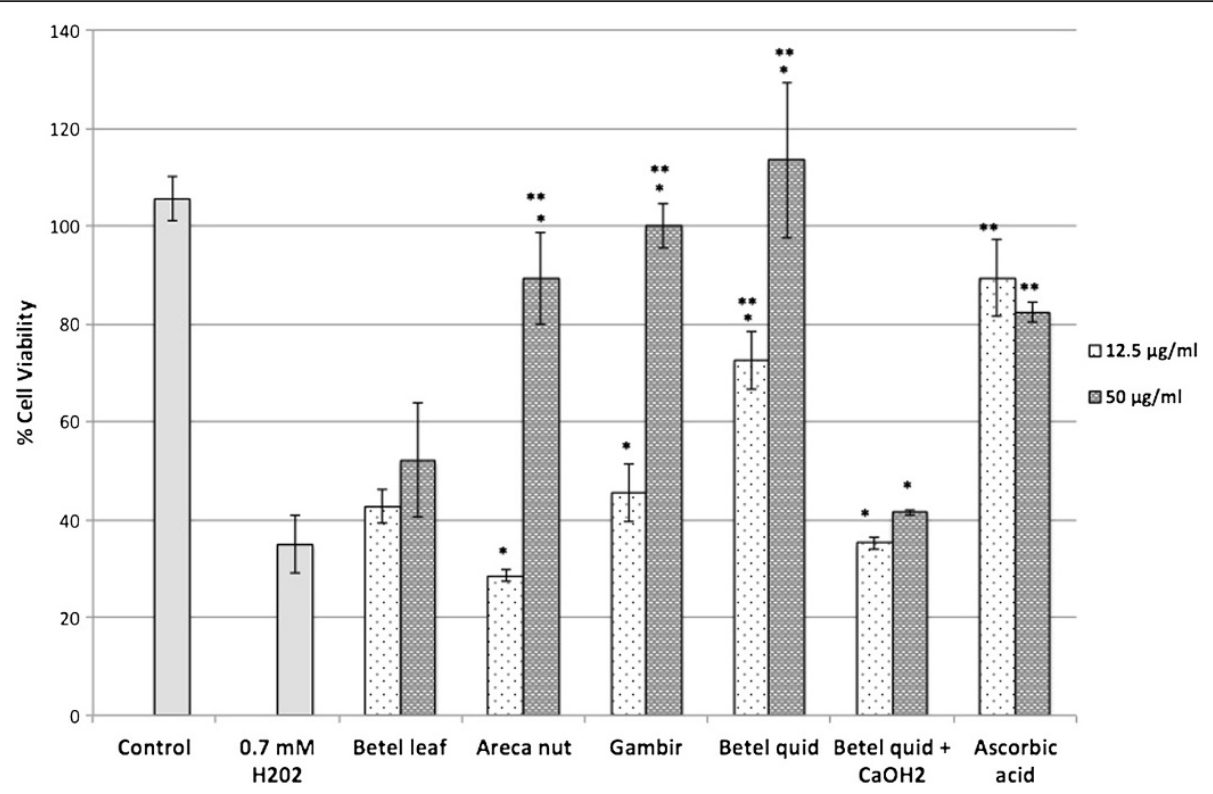

Figure 4 Cytoprotective effects of the extracts against hydrogen peroxide-induced oxidative stress cells. Values are expressed as means \pm SD $(n=3)$. Ascorbic acid was used as positive control. * Significant difference within the same samples at $p<0.05$ (t-test). ${ }^{*}$ Significant difference when compared to $\mathrm{H} 202$ at $p<0.05$ (t-test). 
Table 3 Correlations between TPC with antioxidant and cytoprotective (CP) activities

\begin{tabular}{lllll}
\hline Assay & TPC vs 1/DPPH & TPC vs FRAP & TPC vs FTC & TPC vs CP \\
\hline$r$ value & 0.972 & 0.981 & -0.951 & 0.682 \\
$p$ value & $<0.01$ & $<0.01$ & $<0.01$ & 0.005 \\
\hline
\end{tabular}

activity. However, the negative correlation between lipid peroxidation inhibition activity and its total phenolic content may be related to the fact that only specific phenolic structures are involved in the lipid peroxidation assay [45]. This may explain why extracts with lowest TPC could strongly inhibit the lipid peroxidation.

Basically, the entire oral environment is likely to be exposed to the effects of the extract from betel quid chewing. The quid may be in close contact with the oral mucosa for prolonged periods and sometimes the chewers like to retain the quid in the mouth in the buccal areas that have been reported to correspond to the site of oral injuries [46]. As mentioned by Jeng et al. [47], oral keratinocytes and fibroblasts appear to be the major target cells attacked by the betel quid ingredients. Thus human gingival fibroblast (HGF) was selected to investigate the cytoprotective activity of betel quid (and its respective ingredients) against hydrogen peroxide-induced stress.

The positive correlation between the cytoprotective activity and TPC of the extracts (Table 3 ) indicates that the extracts with high phenolic content, demonstrate cytoprotective capability. This includes the extracts of areca nut, gambir and betel quid that were strongly effective at concentration of $50 \mu \mathrm{g} / \mathrm{mL}$. Cui et al. [48] have reported that the extract containing polyphenolic that showed strong antioxidant activity demonstrated the most potent cytoprotective effects against hydrogen peroxideinduced cell damage. It was also suggested that the highest cytoprotective activity demonstrated by betel quid may be due to synergy effects, which is the interaction of areca nut, gambir and betel leaf to produce a cytoprotective effect greater than their individual effects. The betel quid with calcium hydroxide extracts showed lowest cytoprotective effects and this corresponds to its lowest TPC and there was no radical scavenging activity detected at concentration below than $1 \mathrm{mg} / \mathrm{mL}$.

The possible phenolic compounds related to antioxidant and cytoprotective activities of the extracts are shown in Table 2. The major compound found in gambir was quinic acid. Quinic acid is derived from caffeic acid, a major class of hydroxycinnamic acid. Caffeic acid is present naturally in food as an ester with quinic acid, known as the chlorogenic acid (4-p-coumaroylquinic acid) [49]. Both chlorogenic acid and caffeic acid are antioxidants, protecting low-density lipoprotein (LDL) from oxidation and thus may play a role in preventing many age-related-diseases
[50]. Pero [39] has reported the presence of natural ester of quinic acid in the aqueous extract of Uncaria species (gambir), and the importance of quinic acid as anti-viral, anti-oxidant and anti-aging as well as neurogenerative prevention with health benefit. The quinic acid was also found to be the major compound in betel quid.

The gambir aqueous extract also contains quercetin, which has been reported to have strong antioxidant properties [51]. Quercetin chelates metals, scavenges oxygen free radicals [52] and inhibits lipid peroxidation [53]. In normal cells, quercetin may protect the cells from necrosis and apoptosis [54]. However, it has been found to be more toxic towards malignant cells than normal cells $[55,56]$. It specifically inhibits cell proliferation and induces apoptosis in many cancer cell types [57].

The areca nut contains monomeric, dimeric and trimeric procyanidins that are known to be strong antioxidants. These findings were similar with the one that has been reported by Nonaka et al. [58]. It has been reported that the proanthocyanidins have antitumor, immunomodulatory, antiallergic, antioxidative, chemopreventive, and anti-inflammatory activities $[59,60]$. Catechin, a monomer of procyanidin may also have an influence on the antioxidant and cytoprotective properties in areca nut and gambir. The catechin, which is abundant in areca nut, is said to have a high ability to scavenge free radicals [12].

$p$-Hydroxybenzoic acid is the major compound in the extracts of betel leaf and betel quid. It is an antioxidant and has been used as food preservative. $p$-Hydroxybenzoic, a white crystalline powder is slightly soluble in water. Quinic acid is absent in the betel leaf extract and this may explain for the difference in the antioxidant properties between betel leaf and betel quid. Therefore, the high antioxidant properties demonstrated by betel quid in comparison with betel leaf may be related to the presence of quinic acid.

Hydroxychavicol, eugenol and p-coumaric acid are found in both betel quid and betel quid with calcium hydroxide. $p$-Coumaric acid is an antioxidant, which is a by-product of chlorogenic acid breakdown. $p$-Coumaric may lower serum cholesterol level, constraint low-density lipoprotein (LDL) from being oxidized, and maintain the high-density lipoprotein (HDL) level in addition to its antioxidant properties. The level of $p$-coumaric acid was found to be higher in betel quid than in betel quid with calcium hydroxide. This may explain for the difference in the antioxidant properties between the two.

Hydroxychavicol and eugenol are phenolic compounds commonly found in betel leaves. Hydroxychavicol is said to possess antibacterial $[61,62]$, antioxidant and anticarcinogenic activities [63] whereas eugenol has been used as a local anesthetic for toothaches [64]. In addition, Baliga et al. [65] reported that the eugenol and hydroxychavicol in betel leaf are excellent antimutagens and are 
applicable against wide ranges of environmental carcinogens in both prokaryotes and eukaryotes.

Many studies have reported that hydroxychavicol is a major phenolic compound in the aqueous extract of betel leaves $[1,20,66]$. However our study has shown the absence of hydroxychavicol in the extract of betel leaf. This could be due to different procedure used in the extraction. For instance, the betel leaves were extracted in boiling water $[1,66]$. According to Pin et al. [20], raising the temperature to $60^{\circ} \mathrm{C}$ during extraction could increase the diffusivity and solubility of hydroxychavicol. However the presence of hydroxychavicol in the extract of betel quid and betel quid with calcium hydroxide suggests that the inclusion of areca nut and gambir in the quid may help the diffusivity of hydroxychavicol.

The alkaline condition of betel quid containing slake lime may also contribute to the diffusivity of hydroxychavicol. A significant amount of eugenol in the betel quid could be changed in the presence of calcium hydroxide, hence explaining for its low content in betel quid with calcium hydroxide. Sakano et al., [67] have reported that eugenol can be metabolized into hydroxychavicol in certain conditions. Thus it may suggest that eugenol from betel quid has been metabolized into hydroxychavicol, which resulted in the higher amount of hydroxychavicol in the betel quid containing calcium hydroxide.

Catechin and procyanidin, which are abundant in areca nut and gambir extract, were however absent in the extract of betel quid and betel quid with calcium hydroxide. Several studies have indicated that the stability of the catechin is affected by $\mathrm{pH}$ of the extracts. Zhu et al. [68] have reported that the catechin in green tea with $\mathrm{pH}$ above 8 are particularly unstable and quickly degrades but appears to be very stable at $\mathrm{pH}$ below 4 . Su et al. [69] have also mentioned that the stability of catechins is pH-dependent. In both alkaline and neutral solutions, it is unstable as it decomposes rapidly but in acidic solution, relatively stable.

In this study, the $\mathrm{pH}$ for betel quid was neutral (6.90) and betel quid with calcium hydroxide was slightly alkaline ( $\mathrm{pH}=7.96)$ which explains for the absence of catechins in both the extracts. The absence of $p$-hydroxybenzoic acid and quinic acid in betel quid with calcium hydroxide also could be due to the alkaline nature of the extract. It may suggest that $\mathrm{pH}$ may give significant impact on the stability of phenolic compounds such as $p$-hydroxybenzoic acid, quinic acid and catechin.

\section{Conclusions}

The total phenolic (TPC) content has an influence in radical scavenging, ferric reducing and cytoprotective activity of the extracts. The TPC as well as antioxidant and cytoprotective activities of betel quid (which is greater than betel quid containing calcium hydroxide) maybe associated with the presence of quinic acid. Further research should be carried out to identify and isolate the active compounds of Areca catechu, Uncaria gambir and Piper betle and perhaps betel quid that could be used as alternative sources of antioxidants for therapeutic purposes in oral healthcare.

\section{Competing interests}

The authors declare that they have no competing interest.

\section{Authors' contributions}

NN designated the study, performed all the experiments, statistical analysis and drafted the manuscript. TN has been involved with interpretation of data and LCMS analysis. ZHAR has been involved with the preliminary investigation and revision of the manuscript for intellectual content. All authors read and approved the final manuscript.

\section{Acknowledgements}

The authors are grateful for the financial support (Grant number: PS162/ 2010B) provided by the University of Malaya, Kuala Lumpur. Ms. Nur Sazwi Nordin is a postgraduate student sponsored by the International Islamic University Malaysia.

\section{Author details}

${ }^{1}$ Department of Oral Biology, Faculty of Dentistry, University of Malaya, 50603 Kuala Lumpur, Malaysia. ${ }^{2}$ UCSI University, \#1, Jalan Menara Gading, UCSI Heights, Cheras, 56000 Kuala Lumpur, Malaysia.

Received: 7 June 2013 Accepted: 9 December 2013

Published: 11 December 2013

\section{References}

1. Nalina T, Rahim ZHA: The crude aqueous extract of Piper betle L. and its antibacterial effect towards Streptococcus mutans. Am J Biotechnol Biochem 2007, 3:10-15.

2. Arambewela LSR, Arawwawala LDAM, Ratnasooriya WD: Antidiabetic activities of aqueous and ethanolic extracts of Piper betle leaves in rats. J Ethnopharmacol 2005, 102:239-245.

3. Hajare R, Darvhekar VM, Shewale A, Patil V: Evaluation of antihistaminic activity of piper betel leaf in guinea pig. Afr J Pharm Pharmacol 2011, 5:113-117.

4. Fathilah AR, Sujata R, Norhanom AW, Adenan MI: Antiproliferative activity of aqueous extract of Piper betle L. and Psidium guajava L. on KB and HeLa cell lines. J Med Plants Res 2010, 4:987-990.

5. Bhandare AM, Kshirsagar AD, Vyawahare NS, Hadambar AA, Thorve VS: Potential analgesic, anti-inflammatory and antioxidant activities of hydroalcoholic extract of Areca catechu L. nut. Food Chem Toxicol 2010, 48:3412-3417.

6. Azeez S, Amudhan S, Adiga S, Rao N, Rao N, Udupa LA: Wound healing profile of Areca catechu extracts on different wound models in wistar rats. Kuwait Med J 2007, 39:48-52.

7. Dar A, Khatoon S: Behavioral and biochemical studies of dichloromethane fraction from the Areca catechu nut. Pharmacol Biochem Behav 2000, 65:1-6.

8. Vermani K, Garg S: Herbal medicines for sexually transmitted diseases and AIDS. J Ethnopharmacol 2002, 80:49-66.

9. Taniguchi S, Kuroda K, Doi K, Yoneda Y, Tanabe M, Shibata T, Yoshida T, Hatano T: Evaluation of gambir quality based on quantitative analysis of polyphenolic constituents. Yakugaku Zasshi 2007, 127:1291-1300.

10. Dasgupta N, De B: Antioxidant activity of Piper betle L. leaf extract in vitro. Food Chem 2004, 88:219-222.

11. Li CC, Lin ES: Antiradical capacity and reducing power of different extraction method of Areca Catechu seed. Afr J Biotechnol 2010, 9:7831-7836.

12. Anggraini T, Tai A, Yoshino T, Itani T: Antioxidative activity and catechin content of four kinds of Uncaria gambir extracts from west Sumatra, Indonesia. Afr J Biochem Res 2011, 5:33-38.

13. Lim YY, Lim TT, Tee JJ: Antioxidant properties of several tropical fruits: a comparative study. Food Chem 2007, 103:1003-1008. 
14. Devasagayam TPA, Tilak JC, Boloor KK: Review: free radicals and antioxidants in human health: current status and future prospects. J Assoc Physician India 2004, 52:794-804.

15. Agoramoorthy G, Chen FA, Venkatesalu V, Kuo DH, Shea PC: Evaluation of antioxidant polyphenols from selected mangrove plants of India. Asian J Chem 2008, 20:1311-1322.

16. Anani K, Hudson JB, De-Souza C, Akpagana K, Tower GHN, Arnason JT, Gbeassor M: Investigation of medicinal plants of Togo for antiviral and antimicrobial activities. J Pharm Biol 2000, 38:40-45.

17. Kondo S, Yoshikawa H, Miwa N: Cytoprotective effect of fruit extracts associated with antioxidant activity against ultraviolet rays. Food Chem 2007, 104:1272-1276.

18. Craciunescu O, Constantin D, Gaspar A, Toma L, Utoiu E, Moldovan L: Evaluation of antioxidant and cytoprotective activities of Arnica montana L. and Artemisia absinthium L. ethanolic extracts. Chem Cent J 2012, 6:97.

19. Saeed N, Khan MR, Shabbir M: Antioxidant activity, total phenolic and total flavonoid contents of whole plant extracts Torilis leptophylla $\mathrm{L}$. BMC Complem Altern M 2012, 12:221.

20. Pin KY, Chuah AL, Rashih AA, Mazura MP, Fadzureena J, Vimala S, Rasadah MA: Antioxidant and anti-inflammatory activities of extracts of betel leaves (Piper betle) from solvents with different polarities. J Trop For Sci 2010, 22:448-455.

21. Sullivan RJ, Allen JS, Otto C, Tiobech J, Nero K: Effects of chewing betel nut (Areca catechu) on the symptoms of people with schizophrenia in Palau, Micronesia. Br J Psychiatry 2000, 177:174-178.

22. Reichart PA, Philipsen HP: Betel and Miang: Vanishing Thai habits. 2nd edition. Bangkok: White Lotus Ltd. Co.; 2005.

23. Ghani WMN, Razak IA, Yang Y-H, Talib NA, Ikeda N, Axell T, Gupta CP, Handa $Y$, Abdullah N, Zain RB: Factors affecting commencement and cessation of betel quid chewing behaviour in Malaysian adults. BMC Public Health 2011, 11:1-6.

24. Winstock $A$ : Areca nut-abuse liability, dependence and public health. Addict Biol 2002, 7:133-138.

25. Sharan RN, Choudhury Y: Betel nut and susceptibility to cancer. In Environment factors, genes, and the development of human cancers. Edited by Roy D, Dorak MT. New York: Springer Science Business Media; 2010:401-428.

26. Manigauha A, Ali H, Maheshwari MU: Antioxidant activity of ethanolic extract of Piper betel leaves. J Pharm Res 2009, 2:491-494.

27. Benzie IFF, Strain JJ: Ferric reducing/antioxidant power assay: direct measure of total antioxidant activity of biological fluids and modified version for simultaneous measurement of total antioxidant power and ascorbic acid concentration. Meth Enzymol 1999, 299:15-27.

28. Osawa T, Namiki M: A novel type of antioxidant isolated from leaf wax of eucalyptus leaves. J Agri Biol Chem 1981, 45:735-739.

29. Chandler SF, Dodds JH: The effect of phosphate nitrogen and sucrose on the production of phenolics and sucodisine in callus cultures of Solanum tuberosum. Plant Cell Rep 1983, 2:105-108.

30. Shetty K, Curtis OF, Levin RE, Witkowsky R, Ang W: Prevention of vitrification associated with in vitro shoot culture of oregano (Origanum vulgare) Pseudomonas spp. J Plant Physiol 1995, 147:447-451.

31. Freshney Rl: Culture of animal cells: a manual of basic techniques. Hoboken, New Jersey: John Wiley \& Sons, Inc.; 2005.

32. Khan S, Mehmood MH, Ali ANA, Ahmed FS, Dar A, Gilani AH: Studies on anti-inflammatory and analgesic activities of betel nut in rodents. J Ethnopharmaco 2011, 135:654-661.

33. Alothman M, Bhat $R$, Karim AA: Antioxidant capacity and phenolic content of selected tropical fruits from Malaysia, extracted with different solvents. Food Chem 2009, 115:785-788.

34. Settharaksa S, Jongjareonrak A, Hmadhlu P, Chansuwan W, Siripongvutikorn S: Flavonoid, phenolic contents and antioxidant properties of Thai hot curry paste extract and its ingredients as affected of $\mathrm{pH}$, solvent types and high temperature. Int Food Res J 2012, 19:1581-1587.

35. Maznah I, Elizabeth M, Azlina MD, Asmah R, Asmah Y: Chemical composition and antioxidant activity of Strobilanthes crispus leaf extract. J Nutr Biochem 2000, 11:536-542.

36. Huda-Faujan N, Noriham A, Norrakiah AS, Babji AS: Antioxidant activity of plants methanolic extracts containing phenolic compounds. Afr J Biotechnol 2009, 8:484-489.

37. $\mathrm{Hu} Y, X u$ J, Hu Q: Evaluation of antioxidant potential of Aloe vera (Aloe barbadensis Miller) extracts. Agric Food Chem 2003, 51:7788-7791.
38. Aqil F, Ahmad I, Mehmood Z: Antioxidant and free radical scavenging properties of twelve traditionally used Indian medicinal plants. Turk J Biol 2006, 30:177-183.

39. Pero RW: Historical development of uncaria preparations and their related bioactive components. In DNA damage repair, repair mechanisms and aging. Edited by Thomas AE. New York: Nova Science Publishers, Inc; 2010:223-236

40. Arbain D, Afrida X, Ibrahim S, Sargent MV, Skelton BW, White AH: The alkaloids of Uncaria cf. glabrata. Aust J Chem 1998, 51:961-964.

41. Wirth $\mathrm{C}$, Wagner $\mathrm{H}$ : Pharmacologically active procyanidines from the bark of Uncaria tomentosa. Phytomedicine 1997, 4:265-266.

42. Sekiya N, Shimada Y, Shibahara N, Takagi S, Yokoyama K, Kasahara Y, Sakakibara I, Terasawa K: Inhibitory effects of Choto-san (Diao-teng-san), and hooks and stems of Uncaria sinensis on free radical-induced lysis of rat red blood cells. Phytomedicine 2002, 9:636-640.

43. Verzelloni E, Tagliazucchi D, Conte A: Relationship between the antioxidant properties and the phenolic and flavonoid content in traditional balsamic vinegar. Food Chem 2007, 105:564-571.

44. Ajila CM, Naidu KA, Bhat SG, Prasada RUJS: Bioactive compounds and antioxidant potential of mango peel extract. Food Chem 2007, 105:982-988

45. Locatelli M, Travaglia F, Coïsson JD, Martelli A, Stévigny C, Arlorio M: Total antioxidant activity of hazelnut skin (Nocciola Piemonte PGI): impact of different roasting conditions. Food Chem 2010, 4:1647-1655.

46. Avon SL: Oral mucosal lesions associated with use of quid. J Can Dent Assoc 2004, 70:244-248.

47. Jeng JH, Chang MC, Hahn LJ: Role of areca nut in betel quid associated chemical carcinogenesis: current awareness and future perspectives. Oral Oncol 2001, 37:477-492.

48. Cui Y, Kim D-S, Park K-C: Antioxidant effect of Inonotus obliquus. J Ethnopharmacol 2005, 96:79-85.

49. Tapiero H, Tew KD, Ba GN, Mathe G: Polyphenols: do they play a role in prevention of hu- man pathologies? Biomed Pharmacother 2002, 56:200-207.

50. Robinson WE: HIV integrase: the next target? Infect Med 1998, 15:129-137.

51. Cai Y, Luo Q, Sun M, Corke H: Antioxidant activity and phenolic compounds of 112 traditional Chinese medicinal plants associated with anticancer. Life Sci 2004, 74:2157-2184.

52. Kandaswami C, Middleton E: Free radical scavenging and antioxidant activity of plant flavonoids. Adv Exp Med Biol 1994, 366:351-376.

53. Vulcain E, Goupy P, Caris-Veyrat C, Dangles O: Inhibition of the metmyoglobin-induced peroxidation of linoleic acid by dietary antioxidants: action in the aqueous vs. lipid phase. Free Radical Res 2005, 39:547-563.

54. Arash K: Protective effect of quercetin against necrosis and apoptosis induced by experimental ischemia and reperfusion in rat liver. Afr $J$ Pharm Pharmacol 2010, 4:22-26.

55. Jeong JH, An JY, Kwon YT, Rhee JG, Lee YJ: Effects of low dose quercetin: cancer cell-specific inhibition of cell cycle progression. J Cell Biochem 2009, 106:73-82.

56. Yen GC, Duh PD, Tsai HL, Huang SL: Pro- oxidative properties of flavonoids in human lymphocytes. Biosci Biotechnol Biochem 2003, 67:1215-1222.

57. Kim GN, Jang HD: Protective mechanism of quercetin and rutin using glutathione metabolism on $\mathrm{H} 2 \mathrm{O} 2$ - induced oxidative stress in $\mathrm{HepG} 2$ cells. Ann NY Acad Sci 2009, 1171:530-537.

58. Nonaka GI, Hsu FL, Nishioka I: Structures of dimeric, trimeric, and tetrameric procyanidins from Areca catechu L. J Chem Soc Chem Commun 1981, 15:781-783.

59. Ito H, Kobayashi E, Takamatsu Y, Li SH, Hatano T, Sakagami H, Kusama K, Satoh K, Sugita D, Shimura S, Itoh Y, Yoshida T: Polyphenols from Eriobotrya japonica and their cytotoxicity against human oral tumor cell lines. Chem Pharm Bull 2000, 48:687-693.

60. Zhang XY, Li WG, Wu YJ, Zheng TZ, Li W, Qu SY, Liu NF: Proanthocyanidin from grape seeds potentiates anti-tumor activity of doxorubicin via immunomodulatory mechanism. Int Immunopharmacol 2005, 5:1247-1257.

61. Sharma S, Khan IA, Ali I, Ali F, Kumar M, Kumar A, Johri RK, Abdullah ST, Bani S, Pandey A, Suri KA, Gupta BD, Satti NK, Dutt P, Qazi GN: Evaluation of the antimicrobial, antioxidant and anti-inflammatory activities of hydroxychavicol for its potential use as an oral care agent. Antimicrob Agents Chemother 2009, 53:216-222.

62. Ramji N, Ramji N, lyer R, Chandrasekaran S: Phenolic antibacterials from piper betle in the prevention of halitosis. J Ethnopharmacol 2002, 83:149-152. 
63. Chang MJW, Ko CY, Lin RF, Hsiesh LL: Biological monitoring of environment exposure to Safrole and the Taiwanese betel quid chewing. Arch Environ Contam Toxicol 2002, 43:432-437.

64. Bissa S, Songara D, Bohra A: Traditions in oral hygiene: chewing of betel (Piper betle L.) leaves. Curr Sci 2007, 92:26-28.

65. Baliga MS, Bhat HP, Rao S, Rao P, Palatty PL, Thilakchand KR, Rai MP: Piper Betel Linn (Betel Vine), the Maligned Southeast Asian medicinal plant possesses cancer preventive effects: time to reconsider the wronged opinion. Asian Pac J Cancer Prev 2011, 12:2149-2156.

66. Ali I, Khan FG, Suri KA, Gupta BD, Satti NK, Dutt P, Afrin F, Qazi GN, Khan IA: In vitro antifungal activity of hydroxychavicol isolated from Piper betle L. Ann Clin Microbiol Antimicrob 2010, 9:1-9.

67. Sakano K, Inagaki Y, Oikawa S, Hiraku Y, Kawanishi S: Copper-mediated oxidative DNA damage induced by eugenol: possible involvement of $O$ demethylation. Mutat Res 2004, 565:35-44.

68. Zhu QY, Zhang A, Huang Y, Chen ZY: Stability of green tea catechins. J Agric Food Chem 1997, 45:4624-4628.

69. Su YL, Leung LK, Huang Y, Chen ZY: Stability of tea the aflavins and catechins. Food Chem 2003, 83:189-195.

doi:10.1186/1472-6882-13-351

Cite this article as: Nur Sazwi et al:: Antioxidant and cytoprotective activities of Piper betle, Areca catechu, Uncaria gambir and betel quid with and without calcium hydroxide. BMC Complementary and Alternative Medicine 2013 13:351.

\section{Submit your next manuscript to BioMed Central and take full advantage of:}

- Convenient online submission

- Thorough peer review

- No space constraints or color figure charges

- Immediate publication on acceptance

- Inclusion in PubMed, CAS, Scopus and Google Scholar

- Research which is freely available for redistribution 